\title{
IMPLEMENTASI KEBIJAKAN WAJIB BELAJAR SEMBILAN TAHUN DI DESA KADUARA TIMUR SUMENEP MADURA
}

\author{
Rini Aristin dan Rina Nur Azizah \\ Program Studi Ilmu Administrasi Negara, FIA, Universitas Madura \\ Jl. Raya Panglegur KM. 3,5 Pamekasan \\ Email: rini.aristin@unira.ac.id
}

\begin{abstract}
Abtracts: This study relates to the implementation of the Government Regulation of the Republic of Indonesia Number 47 of 2008 concerning Compulsory Education in the village of Kaduara Timur Sumenep Madura. The researcher uses the implementation model Edward III that the success of the policy according to Edwards III is influenced by four factors, namely, communication, resources, disposition, and bureaucracy. As well as the Koentjoroningrat theory to analyze local cultural values, that according to the Koentjoroningrat elements of culture consist of: (1) language, (2) knowledge systems, (3) social systems or social organizations, (4) living equipment and technology systems, (5) livelihood systems, (6) religious systems, (7) arts. This research is a descriptive research type of qualitative approach. This study describes the community's perspective on education policy in terms of the existing local culture, there is an influence of local culture on the policy. This type of research is a case study, research subjects use purposive sampling and incidental sampling. The researcher acts as an instrument that goes directly to the field to obtain data as accurately as possible, while also using interview, observation and documentation techniques. Data were analyzed using an interactive model (interactive models of analysis) Miles and Huberman which has three main components are: data reduction, data presentation, and draw a conclusion / verification. The results of the study show that the implementation of the Government Regulation on nine-year compulsory education in Kaduara Timur Village has been going well. This is evidenced by $60 \%$ of the villagers who have already and are currently undergoing a normal nine-year education. The success of the government is influenced by the local culture which is still thick but in addition to the local culture the values that develop through the advancement of science and technology also have a special effect on the way of thinking of the people of Kaduara Timur village which then affects the awareness of the people of Kaduara Timur of the importance of education, especially nine years of basic education.
\end{abstract}

Keywords: Policy Implementation, Compulsory Education, Local Culture.

Abstrak: Penelitian ini berkaitan dengan implementasi PP No. 47 tahun 2008 tentang Wajib Belajar di desa Kaduara Timur Sumenep Madura. Peneliti menggunakan model implementasi Edward III bahwa Keberhasilan kebijakan Menurut Edwards III dipengaruhi oleh empat faktor yaitu, komunikasi, sumberdaya, Disposisi, dan Birokrasi. Serta teori Koentjoroningrat untuk menganalisis nilai-nilai budaya lokal, bahwa menurut Koentjoroningrat unsur-unsur kebudayaan terdiri dari: (1) bahasa, (2) sistem pengetahuan, (3) sistem kemasyarakatan atau organisasi sosial, (4) sistem peralatan hidup dan teknologi, (5) sistem mata pencaharian hidup, (6) sistem religi, (7) kesenian. Penelitian ini merupakan 


\section{REFORMASI}

penelitian deskriptif jenis pendekatan kualitatif. Penelitian ini mendeskripsikan tentang perspektif masyarakat terhadap kebijakan pendidikan di tinjau dari budaya lokal yang ada, ada pengaruh budaya lokal terhadap kebijakan tersebut. Subyek penelitian menggunakan purposive sampling dan incidental sampling. Peneliti bertindak sebagai instrumen yang terjun langsung ke lapangan untuk memperoleh data seakurat mungkin selain itu juga menggunakan teknik wawancara, observasi dan dokumentasi. Teknik analisis data menggunakan model analisis interaktif (interactive model of analysis) Miles dan Huberman yang memiliki tiga komponen utama yakni reduksi data, penyajian data sertaverifikasi. Hasil penelitian menunjukkan bahwa implementasi Peraturan pemerintah tentang wajib belajar sembilan tahun di Desa Kaduara Timur telah berjalan dengan baik hal ini dibuktikan dengan $60 \%$ penduduk desa tersebut sudah dan sedang menempuh pendidikan wajar sembilan tahun. Keberhasilan pemerintah tersebut dipengaruhi oleh budaya lokal yang masih kental akan tetapi selain budaya lokal nilai-nilai yang berkembang melalui kemajuan IPTEK juga berpengaruh khususnya pada cara berpikir masyarakat desa Kaduara Timur yang kemudian berdampak pada kesadaran masyarakat Kaduara Timur akan pentingnya Pendidikan khususnya Pendidikan Dasar sembilan tahun.

Kata Kunci: budaya lokal, implementasi kebijakan, wajib belajar.

\section{PENDAHULUAN}

Negara merupakan gabungan dari unsur-unsur yang mewajibkan berdirinya suatu negara. Negara akan berdiri kokoh apabila ketiga unsur negara berada dalam kondisi yang kokoh pula. Rakyat sebagai salah satu unsur pokok dalam satu organisasi yang disebut negara memiliki peranan yang sangat luar biasa penting (vital) dalam menentukan perkembangan suatu negara ke depannya, baik dikalangan regional maupu internasional. Dalam teori kontrak sosial berdirinya suatu negara dikarenakan adanya kesepakatan antara manusia satu dengan manusia yang lainnya untuk berdirinya suatu negara, terlebih lagi negara Indonesia. Indonesia merupakan suatu negara yang tidak hanya memiliki keragaman ras yang menjadi salah satu wadah yang didiami oleh sekumpulan rakyat (warga negara) akan tetapi luasnya wilayah yang terdiri dari gugusan pulau apabila tidak dilandasi kesepakatan (konsensus) antar warga negara satu dengan lainnya maka akan sangat mustahil negara Indonesia berdiri kokoh sampai hari ini. Kesepakatan mengenai berdirinya Indonesia ini telah tercatat dalam sejarah yakni sejak di proklamirkan kemerdekaan Indonesia pada tanggal 17 Agustus 1945. Proklamasi merupakan awal sejarah baru bagi Indonesia karena proklamasi merupakan tanda lahirnya negara Indonesia yang independen dan berdaulat. Kedaulatan ada di tangan rakyat sebagaimana yang diamanatkan dalam konstitusi "Kedaulatan berada di tangan rakyat dan dilaksanakan menurut Undang-Undang Dasar”. Sebagai pemangku kebijakan tertinggi melalui Pemilu rakyat Indonesia menyerahkan wewenangnya kepada para wakil rakyat terpilih yang duduk dalam jajaran pemerintahan baik di bangku legislatif maupun eksekutif. Pemerintah sebagai institusi yang mengemban amanat rakyat wajib memperhatikan serta sekaligus memperjuangkan nasib rakyat melalui regulasi-regulasi yang berpihak pada kepentingan rakyat.

Peraturan Pemerintah Nomor 47 tahun 2008 tentang wajib belajar merupakan salah satu regulasi yang digulirkan pemerintah dalam rangka mewujudkan tujuan nasional Indonesia yang tercantum dalam Pembukaan UUD 1945 alinea keempat yakni 
"mencerdaskan kehidupan bangsa". Melalui kebijakan ini pemerintah mengharapkan seluruh warga negara Indonesia bisa mengenyam pendidikan khususnya pendidikan minimal yakni sekolah dasar sembilan tahun. Tujuan kebijakan akan tercapai apabila sebuah regulasi atau kebijakan di selenggarakan atau diimplementasikan dengan baik. Untuk mengukur keberhasilan implementasi kebijakan peneliti menggunakan teori Implementasi dari Edward III yang terdiri dari empat indikator yakni: Komunikasi, Sumberdaya, Disposisi, dan Birokrasi.

Desa Kaduara Timur Kabupaten Sumenep Madura menjadi lokasi penelitian yang sangat menarik untuk dikaji mengenai implementasi kebijakan wajib belajar sembilan tahun, karena penelitian ini merupakan lanjutan dari penelitian yang pernah dilakukan oleh peneliti pada saat memenuhi tugas akhir untuk mencapai gelar Sarjana. Berdasarkan hasil penelitian sebelumnya di desa ini kesadaran akan pentingnya pendidikan (formal) sangatlah rendah. Berdasarkan hasil penelitian sebelumnya tersebut maka setelah 12 tahun peneliti sangat tertarik untuk mengetahui kondisi serta pandangan masyarakat akan pendidikan mengingat saat ini zaman sudah semakin maju dan masyarakat desa Kaduara Timur juga sudah semakin modern akan tetapi sarana gedung sekolah dasar (SD) tepatnya di kampung gunong desa Kaduara Timur ini sangat memperihatinkan, yakni hanya terdiri dari tiga lokal dan siswanya sedikit adakah kondisi ini di pengaruhi perspektif budaya lokal penduduk desa Kaduara Timur yang masih "apatis pada pendidikan formal". Untuk memudahkan dalam penelitian maka tujuan dilakukannya penelitian ini adalah:1) untuk mengetahui budaya lokal pendudukt desa Kaduara Timur Sumenep Madura, 2) untuk menganalisis Implementasi Kebijakan Wajib Belajar Sembilan Tahun di Desa Kaduara Timur Sumenep Madura, 3) untuk menganalisis pengaruh budaya lokal pada Implementasi Wajib Belajar Sembilan tahun di desa kaduara Timur Sumenep Madura.

\section{Pengertian Kebijakan Publik}

Sebagaimana dikemukakan oleh Nugroho (2012: 12) bahwa kebijakan publik adalah "Setiap keputusan yang di buat oleh negara, sebagai strategi, untuk merealisasikan tujuan dari negara. Kebijakan publik adalah strategi untuk mengantar masyarakat, pada masa awal, memasuki masyarakat pada masa transisi, untuk menuju masyarakat yang dicitacitakan".

Wahab 2010 dalam Ramdhani (2017: 3) menjelaskan bahwa:

1. Kebijakan publik merupakan tindakan sadar yang berorientasi pada pencapaian tujuan dari pada sebagai perilaku/tindakan yang dilakukan secara acak dan kebetulan;

2. kebijakan publik pada hakekatnya terdiri dari tindakan-tindakan yang saling berkaitan dan memiliki pola tertentu yang mangarah pencapaian tujuan tertentu yang dilakukan oleh pemerintah dan bukan merupakan keputusan yang berdiri sendiri;

3. kebijakan publik berkenaan dengan aktivitas dan tindakan yang sengaja dilakukan secara sadar dan terukur oleh pemerintah dalam bidang tertentu;

4. kebijkan publik dimungkinkan bersifat positif dalam arti merupkan pedoman tindakan pemerintah yang harus dilakukan dalam menghadapi suatu masalah tertentu, atau bersifat negatif dalam arti merupakan keputusan pejabat untuk tidak melakukan sesuatu.

\section{Pengertian Implementasi Kebijakan}

Menurut A. Mazmanian dan Paul A. Sabartier dalam Abdul Wahab, (1990:51) mengemukakan bahwa implementasi adalah pelaksanaan keputusan kebijaksanaan dasar, 
biasanya dalam bentuk Undang-Undang namun dapat pula berbentuk perintah-perintah atau keputusankeputusan eksekutif yang penting atau keputusan badan peradilan. Lazimnya keputusan itu mengidentifikasikan masalah-masalah yang ingin dicapai dan berbagai cara untuk menstrukturkan proses implementasinya. Proses ini berlangsung setelah melalui sejumlah tahapan tertentu, biasanya diawali dengan tahapan pengesahan Undang-Undang kemudian output kebijakan dalam bentuk pelaksanaan keputusan oleh badan (instansi) pelaksana, dan akhirnya perbaikan-perbaikan penting terhadap UndangUndang atau peraturan yang bersangkutan.

\section{Model Implementasi Kebijakan}

Keberhasilan kebijakan Menurut Edward III dipengaruhi oleh empat faktor yaitu, komunikasi, sumberdaya, Disposisi, dan Birokrasi. Oleh karena dalam penelitian ini Model implementasi yang digunakan adalah Model Edward III.

Sebagaimana dikutip oleh widodo (2010) dalam pandangan Edward III (1980), dikatakan bahwa terdapat faktor atau variabel kritis dalam implementasi kebijakan publik, yaitu : komunikasi, sumberdaya, disposisi (sifat kecenderungan), dan struktur birokrasi. (Widodo, 2010:96) secara terperinci Edward III (1980) menjelaskan keempat faktor tersebut sebagai berikut :

1 komunikasi diartikan sebagai "proses penyampaian informasi komunikator kepada komunikan". Informasi mengenai kebijakan publik menurut Edward III dalam Widodo (2010: 97) perlu disampaikan kepada pelaku kebijakan agar para pelaku kebijakan dapat mengetahui apa yang harus mereka persiapkan dan lakukan untuk menjalankan kebijakan tersebut sehingga tujuan dan sasaran kebijakan dapat dicapai sesuai dengan yang diharapkan. Menurut Edward III dalam Widodo (2010: 97), komunikasi kebijakan memiliki beberapa dimensi, antara lain dimensi transmisi (trasmission), kejelasan (clarity) dan konsistensi (consistency),

1) Dimensi transmisi menghendaki agar kebijakan publik disampaikan tidak hanya disampaikan kepada pelaksana (implementors) kebijakan tetapi juga disampaikan kepada kelompok sasaran kebijakan dan pihak lain yang berkepentingan baik secara langsung maupun tidak langsung.

2) Dimensi kejelasan (clarity) menghendaki agar kebijakan yang ditrasmisikan kepada pelaksana, target grup dan pihak lain yang berkepentingan secara jelas sehingga diantara mereka mengetahui apa yang menjadi maksud, tujuan, sasaran, serta substansi dari kebijakan publik tersebut sehingga masing-masing akan mengetahui apa yang harus dipersiapkan serta dilaksanakan untuk mensukseskan kebijakan tersebut secara efektif dan efisien.

3) Dimensi konsistensi (consistency) diperlukan agar kebijakan yang diambil tidak simpang siur sehingga membingungkan pelaksana kebijakan, target grup dan pihak-pihak yang berkepentingan.

2 Sumberdaya, Edward III dalam Widodo (2010:98) mengemukakan bahwa faktor sumberdaya mempunyai peranan penting dalam implementasi kebijakan. Sumberdaya Manusia merupakan salah satu variabel yang mempengaruhi keberhasilan pelaksanaan kebijakan.

1) Sumberdaya Anggaran, Edward III menyatakan dalam kesimpulan studinya bahwa terbatasnya sumber daya anggaran akan mempengaruhi keberhasilan pelaksanaan kebijakan. Disamping program tidak bisa dilaksanakan dengan optimal, 
keterbatasan anggaran menyebabkan disposisi para pelaku kebijakan rendah.

2) Sumberdaya Peralatan, Edward III menyatakan bahwa sumberdaya peralatan merupakan sarana yang digunakan untuk operasionalisasi implementasi suatu kebijakan yang meliputi gedung, tanah, dan sarana yang semuanya akan memudahkan dalam memberikan pelayanan dalam implementasi kebijakan.

3) Sumberdaya Kewenangan, Sumberdaya lain yang cukup penting dalam menentukan keberhasilan suatu implementasi kebijakan adalah kewenangan. Edward III menyatakan bahwa Kewenangan (authority) yang cukup untuk membuat keputusan sendiri yang dimiliki oleh suatu lembaga akan mempengaruhi lembaga itu dalam melaksanakan suatu kebijakan. Kewenangan ini menjadi penting ketika mereka dihadapkan suatu masalah dan mengharuskan untuk segera diselesaikan dengan suatu keputusan. Oleh karena itu, menurut Edward III bahwa pelaku utama kebijakan harus diberi wewenang yang cukup untuk membuat keputusan sendiri untuk melaksanakan kebijakan yang menjadi kewenangannya.

3 Disposisi, Pengertian disposisi menurut Edward III dalam Widodo (2010:104) dikatakan sebagai "kemauan, keinginan dan kecenderungan para perlaku kebijakan untuk melaksanakan kebijakan tadi secara sungguh sungguh sehingga apa yang menjadi tujuan kebijakan dapat diwujudkan".

Faktor-faktor yang menjadi perhatian Edward III dalam Agustinus (2006:159-160) mengenai disposisi dalam implementasi kebijakan terdiri dari: Pengangkatan birokrasi. Disposisi atau sikap pelaksana akan menimbulkan hambatan-hambatan yang nyata terhadap implementasi kebijakan bila personel yang ada tidak melaksanakan kebijakan yang diinginkan oleh pejabat-pejabat yang lebih atas. Karena itu, pengangkatan dan pemilihan personel pelaksana kebijakan haruslah orang-orang yang memiliki dedikasi pada kebijakan yang telah ditetapkan, lebih khusus lagi pada kepentingan warga masyarakat. Insentif merupakan salah-satu teknik yang disarankan untuk mengatasi masalah sikap para pelaksana kebijakan dengan memanipulasi insentif.

4 Struktur birokrasi, Ripley dan Franklin dalam Winarno (2005:149-160) mengidentifikasi enam karakteristik birokrasi sebagai hasil pengamatan terhadap birokrasi di Amerika Serikat, yaitu:

1) Birokrasi diciptakan sebagai instrumen dalam menangani keperluan-keperluan publik (public affair).

2) Birokrasi merupakan institusi yang dominan dalam implementasi kebijakan publik yang mempunyai kepentingan yang berbeda-beda dalam setiap hierarkinya.

3) Birokrasi mempunyai sejumlah tujuan yang berbeda

4) Fungsi birokrasi berada dalam lingkungan yang kompleks dan luas.

5) Birokrasi mempunyai naluri bertahan hidup yang tinggi dengan begitu jarang ditemukan birokrasi yang mati.

6) Birokrasi bukan kekuatan yang netral dan tidak dalam kendali penuh dari pihak luar.

\section{Pengertian Pendidikan}

Pendidikan adalah usaha atau proses mendidik atau mengajar seperti dikenal seharihari. Mulyohardjo (2012) sebagimana dikutip oleh Triwiyanto (2015: 22) memberikan pengertian pendidikan dalam tiga jangkauan yaitu: pengertian pendidikan maha luas, 
sempit dan luas terbatas. Definisi maha luas, yaitu mendidikan adalah hidup. Pendidikan adalah segala pengalaman belajar yang berlangsung dalam segala lingkungan dan sepanjang hidup. Pendidikan adalah situasi yang mempengaruhi pertumbuhan individu.

Definisi sempit, yaitu pendidikan adalah sekolah. Pendidikan adalah pengajaran yang diselenggarakan di sekolah sebagai lembaga pendidikan formal. Pendidikan adalah segala pengaruh yang diupayakan sekolah terhadap anak dan remaja yang diserahkan kepadanya agar mempunyai kemampuan yang sempurna dan kesadaran penuh terhadap hubungan-hubungan dantugas-tugas sosial mereka.

Sementara itu, definisi luas terbatas, yaitu pendidikan adalah usaha sadar yang dilakukan oleh keluarga, masyarakat, dan pemerintah, melalui kegiatan bimbingan, pengajaran, dan/atau latihan yang berlangsung di sekolah dan di luar sekolah sepanjang hayat untuk memeprsiapkan peserta didik agar dapat memainkan peranan dalam berbagai lingkungan hidup secara tepat di masa yang akan datang. Pendidikan adalah pengalamanpengalaman belajar teprogram dalam bentuk pendidikan formal, nonformal, dan informal di sekolah dan luar sekolah yang berlangsung seumur hidup yang bertujuan optimalisasi kemampuan-kemampuan individu, agar dikemudian hari memainkan peranan secara tepat.

Berdasarkan konsep UU Nomor 20 tahun 2003 tentang SISDIKNAS pasal 1 menyebutkan bahwa pendidikan adalah " usaha sadar dan terencana untuk mewujudkan suasana belajar dan proses pembelajaran agar peserta didik secara aktif mengembangkan potensi dirinya untuk memiliki kekuatan spiritual keagamaan, pengendalian diri, kepribadian, kecerdasan, akhlak mulia serta keterampilan yag diperlukan dirinya, masyarakat bangsa dan negara.

Sehingga dari beberapa definisi di atas dapat ditarik kesimpulan bahwa pendidikan adalah usaha yang dilakukan secara sistematis dan terprogram untuk menyiapkan manusia memiliki kemampuan dan keterampilan agar mampu mengembangkan dirinya sekarang dan di masa yang akan datang.

\section{Jenis-Jenis Pendidikan dalam Masyarakat}

Undang-undang Nomor 20 tahun 2003 tentang SISDIKNAS pasal 13 menjelaskan: "jalur pendidikan terdiri atas pendidikan formal, nonformal, dan informal yang dapat saling melengkapi dan memperkaya”. Kemudian dilanjutkan dalam pasal 15 yang menyebutkan jenis pendidikan mencakup pendidikan umum, kejuruan, akademik, profesi, vokasi, keagamaan dan khusus.

Adapun jenis-jenis pendidikan dalam masyarakat adalah sebagai berikut:

\section{Pendidikan Formal}

Pendidikan formal merupakan pendidikan persekolahan yang berupa rangkaian jenjang pendidikan yang baku. Pendidikan formal terdiri atas jenjang pendidikan dasar, pendidikan menengah dan pendidikan tinggi (pasal 14 UU SISDIKNAS, 2003:68).

2. Pendidikan Informal

Undang-Undang SISDIKNAS Nomor 20 tahun 2003 menjelaskan Pendidikan informal adalah kegiatan pendidikan informal yang dilakukan di keluarga dan lingkungan berbentuk kegiatan belajar secara mandiri.

3. Pendidikan Non Formal

Pendidikan nonformal merupakan apa saja kegiatan yang terorganisasi di luar kerangka sekolah formal yang ada, yang bertujuan untuk mengkomunikasikan gagasan-gagasan tertentu, pengetahuan, keterampilan-keterampilan, sikap-sikap dan praktek-praktek 
sebagai jawaban terhadap kebutuhan yang telah ditetapkan terlebih dahulu (Imran dalam Aristin, 2004: 12).

Pasal 26 ayat (3) UU Nomor 20 tahun 2003 tentang SISDIKNAS menjelaskan bahwa pendidikan non formal meliputi pendidikan kecakapan hidup, pendidikan anak usia dini, pendidikan pemberdayaan perempuan, pendidikan keaksaraan, pendidikan keterampilan dan pelatihan kerja, pendidikan kesetaraan, serta pendidikan lain yang ditujukan untuk mengembangkan kemampuan peserta didik.

\section{Pengertian Budaya Lokal}

Konsep budaya lokal menunjukkan identitas suatu kebudayaan yang lahir berkembang dan mapan di suatu wilayah yang jelas batas dalam konteks geografis yang didukung oleh komunitas tertetu (Lutan dalam Imade dalam Aristin, 2004: 22). Karena itu budaya lokal juga mengandung konotasi kebudayaan suku, bangsa (etnis), sementara kelompok etnis itu pengelompokannya cukup rumit tetapi dapat didasarkan pada kriteria tertentu seperti kekerabatan, sistem kepercayaan, adat-istiadat dan sebagainya. Istilah keompok etnis dapat diartikan kelompok orang yang memiliki keturunan dan warisan yang sama saling memberikan kontribusi budaya yang disepakati bersama dan diwariskan dari generasi kegenerasi.

Menurut Geert ( dalam Yunus, 2016 : 67) kebuadayaan adala pola dari pengertianpengertian atau makna yang terjalin secara menyeluruh dalam simbol-simbol yang ditransmisikan secara historis, suatu sistem mengenai konsepsi-konsepsi yang diwariskan dalam bentuk-bentuk simbolik yang dengan cara tersebut manusia berkomunikasi, melestarikan dan mengembangkan pegetahuan dan sikap mereka terhadap kehidupan. Artinya kebudayaan merupakan hasil karya manusia yang dapat berkembang serta diwariskan secara turun temurun melalui proses komunikasi.

Menurut Porter dan Samovar (dalam Imade dalam Aristin, 2004:22) untuk mengkaji komunikasi antar budaya perlu dipahami antara kebudayaaan dengan komunikasi, melalui pengaruh budayalah manusia belajar berkomunikasi dan memandang mereka melalui kategori, konsep, dan label yang dihasilkan budaya, cara manusia berkomunikasi, keadaan komunikasi bahasa dan gaya bahasa yang digunakan perilaku non verbal merupakan respon terhadap dan fungsi budaya komunikasi. Manusia terikat oleh budaya, sebagaimana budaya berbeda antara yang satu dengan yang lainnya, maka praktek-praktek dan perilaku komunikasi dalam budaya akan berbeda pula. Dalam komunikasi terdapat tiga unsur budaya yang mempunyai pengaruh langsung dan besar atas makna yang dibangun yaitu kepercayaan (belief), nilai (value), sikap (attitude), pandangan dunia (world view), dan organisasi sosial.

Menurut Koentjaraningrat unsur-unsur kebudayaan meliputi: (1) bahasa, (2) sistem pengetahuan, (3) sistem kemasyarakatan dan organisasi sosial, (4) sistem peralatan hidup dan teknologi, (5) sistem mata pencaharian hidup, (6) sistem religi, (7) kesenian (Koentjoroningrat, 2002:203). Unsur kebudayaan menurut Koentjoroningrat inilah yang akan digunakan peneliti sebagai pisau analisis untuk menggali budaya lokal yang ada di lokasi penelitian yakni desa Kaduara Timur Kecamatan Pragaan Kabupaten Sumenep. 
REFORMASI

ISSN 2088-7469 (Paper) ISSN 2407-6864 (Online)

Volume 8 Nomor 2 (2018)

\section{METODE PENELITIAN}

\section{Jenis Penelitian}

Penelitian ini menggunakan pendekatan kualitatif jenis penelitian studi kasus. Studi kasus merupakan serangkaian kegiatan penyelidikan untuk mendeskripsikan dan menganalisis secara intensif dan terperinci suatu gejala atau unit sosial tertentu seperti individu, kelompok, komunitas atau lembaga. Penelitian kasus adalah suatu penelitian yang dilakukan secara intensif, terinci dan mendalam terhadap suatu organisasi, lembaga atau gejala tertentu. Ditinjau dari wilayahnya, maka penelitian kasus hanya meliputi daerah atau subyek yang sempit, tetapi ditinjau dari sifat penelitian, penelitian kasus yang mendalam. Alasan penulis memilih jenis penelitian studi kasus ini karena ruang lingkup penelitian tergolong sempit, yakni hanya sebatas desa. Oleh karena itu untuk mendapatkan hasil penelitian yang lebih mendalam peneliti mengambil jenis penelitian studi kasus ini.

\section{Subyek Penelitian}

Sebelum melakukan penelitian, peneliti terlebih dahulu mencari dan menetapkan informan. Informan dalam penelitian ini adalah seorang pembicara asli yang berbicara dalam bahasa atau dialeknya sendiri sebagai sumber informasi. Oleh karena itu dalam menentukan informan peneliti menggunakan metode:

1. purposive sampling yaitu kepala desa, dan 3 orang aparatur desa, 1 orang sesepuh desa,

2. Incidental sampling yaitu beberapa warga desa dan beberapa orang anak yang masih dalam usia sekolah (formal).

\section{Instrumen dan Teknik Pengumpulan Data}

Sebagai penelitian kualitatif dengan jenis studi kasus, instrumen penelitian ini adalah human instrument, yaitu peneliti berperan sebagai instrumen utama yang tidak dapat diganti/diwakilkan kepada orang lain. Dalam hal ini, peneliti berhubungan langsung dengan penelitian dan berperan sebagai pengumpul data melalui pengumpulan data pustaka, wawancara, observasi dan dokumentasi.

Teknik pengumpulan data dalam penelitian ini terdiri atas dua bagian, yaitu :

1. Pengumpulan Data Pustaka, yaitu dengan mencari berbagai literatur yang berkaitan nilai-nilai budaya lokal.

2. Pengumpulan data di lapangan terdiri dari 3 bagian yaitu :

1) Wawancara, yaitu usaha untuk mengumpulkan data lisan yang tidak dapat diamati secara langsung.

2) Observasi, yaitu usaha untuk mengumpulkan data di lapangan dengan mengadakan pengamatan langsung di lapangan dan survey secara langsung terhadap aktivitasaktivitas masyarakat Madura untuk mengetahui interpretasi, makna sosial dan halhal lainnya yang berhubungan dengan penelitian.

3) Dokumentasi, Saat melakukan wawancara dan pengamatan, peneliti dapat sekaligus membuat dokumentasi atau mengambil gambar yang dapat dijadikan data pelengkap dalam penelitian. 
REFORMASI

ISSN 2088-7469 (Paper) ISSN 2407-6864 (Online)

Volume 8 Nomor 2 (2018)

Teknik Analisis Data

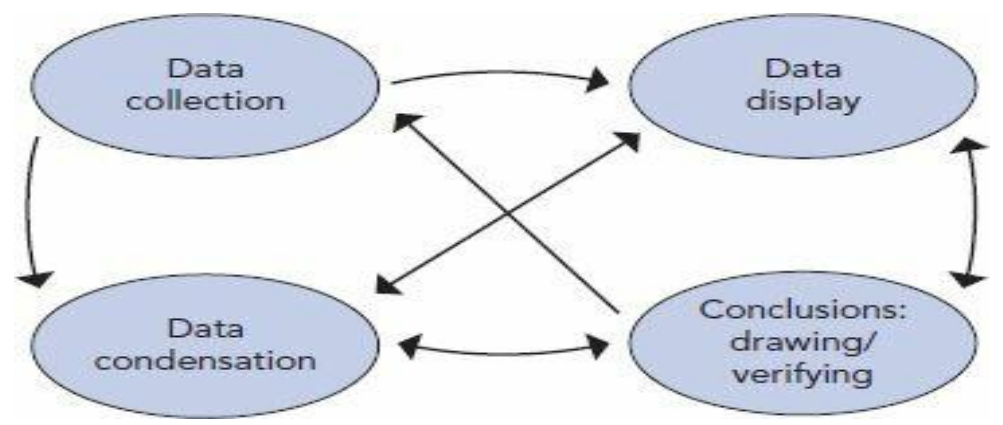

Gambar : Analisis Data Milles \& Huberman

Adapun langkah-langkah analisis data penelitian ini menggunakan model analisis interaktif (interactive model of analysis) Miles dan Huberman yang memiliki tiga komponen utama antara lain : reduksi data, penyajian data, dan menarik suatu kesimpulan/ verifikasi.

1) Pengumpulan Data (Data Colletion) adalah Pengumpulan data merupakan bagian integral dari kegiatan analisis data. Kegiatan pengumpulan data pada penelitian ini adalah dengan menggunakan wawancara dan studi dokumentasi

2) Kondensasi Data (Data Condensation) mengacu pada proses pemilihan, fokus, menyederhanakan, abstrak, dan / atau mengubah data yang muncul dalam catatan lapangan, wawancara, transkrip, dokumen, dan bahan-bahan empiris lainnya. Dengan kondensasi, kita membuat data yang lebih kuat. Data kondensasi terjadi terus menerus sepanjang penelitian kualitatif.

3) Penyajian Data (Data Display) dalam penelitian kualitatif, penyajian data bisa dilakukan dengan bentuk uraian singkat, berupa bagan, hubungan antar kategori dan sejenisnya. Dalam penelitian ini, penyajian data diberikan dalam bentuk teks yang bersifat naratif. Pada tahapan ini, data yang telah diolah kemudian dianalisis lebih lanjut secara mendalam dan menyeluruh.

4) Conclusion Drawing/Verification (Kesimpulan dan Verifikasi). Tahap ini merupakan tahap terakhir dalam rangkaian analisis data kualitatif. Pada tahap terakhir ini, peneliti akan melakukan uji kebenaran dari setiap makna yang muncul maupun klasifikasi dari data yang telah dibuat melalui bagan. Kesimpulan awal yang dikemukakan masih bersifat sementara, dan akan berubah apabila tidak ditemukan bukti-bukti kuat yang mendukung pada tahap pengumpulan data berikutnya. Data yang dikemukakan diuji kebenarannya dengan menganalisis dan mengklarifikasikannya kembali, lalu menguji keabsahannya dengan informan di lapangan maupun melalui diskusi.

Keempat hal utama data collection, data condensation, data display atau penyajian data dan penarikan kesimpulan/verifikasi sebagai suatu yang jalin-menjalin pada sebelum, selama dan sesudah pengumpulan data dalam bentuk interaktif, untuk wawasan umum yang disebut "analisis".

\section{HASIL DAN PEMBAHASAN}

\section{Budaya Lokal Warga Desa Kaduara Timur}

Budaya lokal merupakan budaya warisan nenek moyang dan terefleksikan dalam bentuk simbol serta keberadaannya terus dipelihara dari generasi ke generasi. Unsur-unsur 


\section{REFORMASI}

kebudayaan yang berkembang dalam masyarakat pada umumnya menurut Koentjaraningrat terdiri dari tujuh unsur yaitu:

\section{Bahasa}

Bahasa ditempatkan diurutan pertama karena karena menurut Bronislaw Malinowski seorang antropolog modern bahasa merupakan unsur budaya yang terlebih dahulu ada dalam kebudayaan manusia. (Sugeng, 2009: 122).

Bahasa membantu manusia dalam memahami dan menggunakan simbol, khususnya simbol verbal dalam pemikiran dan berkomunikasi. Sebagaimana dikatakan oleh Leslie White "semua kebudayaan (peradaban) tergantung pada simbol. Kemampuan penggunaan simbollah yang melahirkan kebudayaan dan penggunnaan simbollah yang dapat mempertahankan kebudayaan. Tanpa simbol, tidak akan ada kebudayaan, dan manusia hanyalah binatang, dan bukan manusia”. (Sugeng, 2009:123)

Di Desa Kaduara Timur bahasa Madura menjadi alat komunikasi yang digunakan dalam kehidupan sehari-hari. Penggunaan bahasa Madura dalam kehidupan sehari-hari ini ada tingkatan-tingkatan tutur katanya tergantung dengan siapa yang menjadi lawan bicaranya. Tingkatan tutur dalam bahasa Madura ini dibagi lagi menjadi tiga yaitu: enjeg-iye, enggi-enten, enggi-bhunten. Pemakaian bahasa di sesuaikan dengan situasi serta lawan bicara yang dihadapi:

1) Enjeq- iya: digunakan untuk pergaulan sehari-hari apabila berkomunikasi dengan yang seumuran atau dengan orang lain yang memiliki hubungan yang sangat akrab.

2) Engghi - Enten : digunakan dalam pergaulan sehari-hari apabila berkomunikasi dengan orang yang lebih tua atau orang yang belum dikenal.

3) Engghi-Bhunten: digunakan untuk berkomunikasi dengan seseorang yang sangat dihormati, memiliki perngaruh, serta pada situasi yang sangat resmi.

\section{Sistem pengetahuan}

\begin{tabular}{|l|c|c|}
\hline \multicolumn{1}{|c|}{ Lulusan } & Jumlah Penduduk & Persentase \\
\hline Sekolah Dasar & \pm 1.150 jiwa & $42 \%$ \\
\hline Sekolah Menengah pertama & \pm 493 jiwa & $18 \%$ \\
\hline Sekolah Menengah Atas & \pm 821 jiwa & $30 \%$ \\
\hline Lulus S1, S2, S3 & \pm 164 jiwa & $6 \%$ \\
\hline Balita dan lanjut usia & \pm 109 jiwa & $4 \%$ \\
\hline
\end{tabular}

Sumber : Dokumen Desa Kaduara Timur (17 Mei 2018)

Tabel tersebut menjelaskan bahwa 60 persen penduduk desa Kaduara Timur Sumenep Madura telah menempuh jalur pendidikan formal minimal (Wajib belajar sembilan tahun). Sisa 34 persen lainnya sudah menempuh jalur pendidikan ke jenjang yang lebih tinggi dan sisa 6 persen memang untuk usia yang tidak memaungkinkan untuk menempuh jalur pendidikan formal karena faktor usia yang sudah lanjut atau dikarenakan masih balita.

Data yang tersaji dalam tabel menggambarkan keberhasilan program pendidikan minimal wajib belajar sembilan tahun di desa Kaduara Timur Sumenep Madura. 
REFORMASI

ISSN 2088-7469 (Paper) ISSN 2407-6864 (Online)

Volume 8 Nomor 2 (2018)

\section{Sistem kemasyarakatan atau organisasi sosial}

Para pemuda serta ibu-ibu rumah tangga di desa Kaduara Timur sangat aktif dalam organisasi kemasyarakatan, sebagaimana yang disampaikan oleh Bapak Kepala Desa kaduara Timur yang menyatakan ada beberapa organisasi kemayarakatan yang berkembang di desa Kaduara Timur, adapun organisasi-organisasi kemasyarakatan yang ada di desa ini adalah sebagai berikut: a) Karang Taruna, b) REMAS, c) PKK, d) GABOTAN (Gabungan Kelompok Tani) , e) KOPWAN (Koperasi Wanita), f) POPMAS, g) KUBE, h) Kelompok Nelayan.

\section{Sistem peralatan hidup dan teknologi}

Sistem peralatan hidup masyarakat desa Kaduara Timur sebagian besar sudah canggih dan teknologi sudah modern hal ini terlihat dari perlatan yang digunakan dalam kehidupan seharai-hari baik dalam kehidupan rumah tangga maupun dalam pergaulan antar sesama masyarakat desa Kaduara Timur. Misalnya penggunaan telepon genggam sebagai alat komunikasi dan sepeda motor sebagai alat transportasi.

\section{Sistem mata pencaharian hidup}

Mata pencaharian hidup masyarakat desa kaduara Timur dapat dikelompokkan menjadi empat, yaitu: petani, pedagang, peternak dan nelayan.

\section{Sistem religi}

Agama penduduk desa kaduara Timur adalah Islam dan nilai-nilainya sangat kental mempengaruhi kehidupan penduduk masyarakat desa Kaduara Timur tersebut. Akan tetapi nilai-nilai religi tersebut tidak menjadikan msyarakat desa kaduara timur anti terhadap perkembangan kebudayaan yang positif dan logis menurut mereka.

\section{Kesenian}

Kesenian yang berkembang saat ini di desa Kaduara Timur adalah gambus, ul-daul dan marawis, kesenian yang sudah mengalami kepunahan yang sekaligus budaya lokal khas madura pada umumnya dan desa Kaduara Timur khususnya adalah seni ludruk dan seni macapat. Tergerusnya seni ludruk dan seni macapat yang notabenenya merupakan budaya lokal dikarenakan para pegiat seni dalam bidang tersebut sudah sepuh dan bahkan banyak yang sudah meninggal serta tidak adanya generasi penerus. Generasi muda lebih suka kesenian yang sifatnya modern dan mewakili keinginan masyarakat kekinian.

\section{Implementasi Kebijakan Pendidikan Wajib Belajar (Wajar) Sembilan Tahun di Desa Kaduara Timur}

Keberadaan Perturan pemerintah nomor 47 tahun 2008 tentang pelaksanaan pendidikan minimal sembilan tahun ini dipandang sangat penting karena dua hal. Pertama, pemerintah berupaya mewujudkan tujuan nasional yang tertuang dalam konstitusi yakni "mencerdaskan kehidupan bangsa" hal ini dapat terwujud apabila warga negara sudah menempuh jalur pendidikan khususnya pendidikan formal minimal yang berupa wajib belajar sembilan tahun (Wajar sembilan tahun). Kedua, agar negara Indonesia sebagai negara berkembang mampu mensejajarkan diri dengan negara-negara maju di dunia, karena salah satu indikator sebuah negara di kategorikan negara maju apabila tingkat pendidikannya tinggi dan berkualitas. Dengan lahirnya kebijakan pendidikan minimal ini harapan pemerintah adalah segenap warga negara Indonesia bisa menempuh setidaknya pendidikan formal dari jenjang Sekolah Dasar sampai Jenjang Sekolah Menengah apalagi kalau sampai meneruskan ke jenjang yang lebih tinggi lagi. 
Penelitian ini mengkomparasikan kebijakan pemerintah yaitu kebijakan Nomor 47 Tahun 2008 tentang program Wajib Belajar Sembilan Tahun dengan Teori Implementasi dari Edward III. Bahwa menurut Edward III keberhasilan implementasi kebijakan di pengaruhi indikator-indikator berikut:

\section{Komunikasi Kebijakan Pendidikan Wajib Belajar (Wajar) Sembilan Tahun di Desa Kaduara Timur}

Menurut Edward III terkait proses komunikasi ada tiga hal penting yang perlu di perhatikan, yaitu :

a) Transmisi: kebijakan publik tidak hanya disampaikan kepada pelaksana akan tetapi juga kepada kelompok sasaran baik secara langsung maupun tidak langsung. Implementasi Program Wajib Belajar juga sangat membutuhkan variabel ini yaitu dengan adanya Sosialisasi. Berdasarkan hasil wawancara dengan kepala desa Kaduara Timur secara langsung tidak pernah diadakan sosialisasi dari pihak terkait tentang Implementasi PP nomor 47 Tahun 2008 di Desa Kaduara Timur.

b) Kejelasan: kebijakan yang di transmisikan baik kepada pelaksana, target kelompok dan pihak pihak lain dibarengi dengan kejelasan agar mereka pihak komunikan bisa memahami dengan jelas maksud, tujuan maupun substansi agar pelaksanaan kebijakan berjalan sukses. Proses penyampaian informasi yang jelas sangat berpengaruh terhadap keberhasilan suatu program, program Wajib Belajar Sembilan Tahun sudah disampaikan dengan jelas terbukti dengan lahirnya Kebijakan Pemerintah nomor 47 tahun 2008, akan tetapi warga setempat di desa Kaduara Timur tidak semuanya mengerti tentang Kebijakan pemerintah Nomor 47 Tahun 2008, apalagi tidak pernah diadakan sosialisasi ke desa ini yang secara khusus menyampaikan kebijakan tersebut kepada penduduk desa Kaduara Timur Sumenep Madura.

c) Konsistensi: diperlukan konsistensi pada sebuah kebijakan agar pelaksana, sasaran kelompok tidak kebingungan pada saat mengimplementasikan kebijakan. Terkait kebijakan wajib belajar sembilan tahun ini pemerintah masih konsisten karena sampai detik ini kebijakan tersebut masih berlaku atau belum ada peraturan baru di buat untuk menggantikan kebijakan tersebut.

\section{Sumber Daya Kebijakan Pendidikan Wajib Belajar (Wajar) Sembilan Tahun di Desa Kaduara Timur}

Menurut Edward III Sumber Daya mempunyai peranan penting dalam implementasi kebijakan, sumber daya ini meliputi:

a) Sumber daya manusia:

1. terkait dengan SDM pemangku kebijakan wajib belajar sembilan tahun di desa Kaduara Timur ini sudah sesuai dan kualifikasi dan kapabilitasnya akan tetapi sangat minim dalam hal integritas.

2. Penduduk desa Kaduara Timur sangat memegang teguh nilai-nilai budaya khusunya nilai religi dan juga sangat welcome terhadap perkembangan informasi. Sehingga walaupun mereka tidak pernah mendengar secara langsung akan adanya program wajib belajar sembilan tahun ini, akan tetapi tingkat pendidikan penduduk desa ini $60 \%$ sudah melaksanakan program pemerintah tersebut. 
b) Sumber Daya Peralatan: hal ini meliputi bangunan fisik seperti gedung persekolahan yang menjadi pendukung utama penyelenggaraan program pemerintah agar terlaksana dengan baik. Fakta di lapangan menunjukkan Fasilitas (gedung Sekolah Dasar) di desa Kaduara Timur hanya terdiri dari tiga lokal saja sehingga setiap kelas diisi oleh dua kelas yang menggunakan batas pemisah berupa triplek. Kenyataan ini tentu sangat bertentangan dengan data yang menunjukkan bahwa $60 \%$ warga desa Kaduara Timur Sumenep Madura sudah menempuh jalur pendidikan formal minimal yakni Program Pemerintah terkait Wajib Belajar Sembilan Tahun. Setelah peneliti melakukan wawancara dengan warga desa dan juga kepala desa ternyata sebagian besar warga desa Kaduara Timur tidak bersekolah di SDN Kaduara Timur milik pemerintah ini akan tetapi mereka (warga desa) menyelesaikan pendidikan minimal mereka di yayasan dan pondok pesantren.

\section{Disposisi Kebijakan Pendidikan Wajib Belajar (Wajar) Sembilan Tahun di Desa Kaduara Timur}

Menurut Edward III dalam Widodo (2010:104) meliputi kemauan, keinginan dan kecenderungan para pelaku kebijakan untuk melaksanakan kebijakan secara sungguhsungguh sehingga apa yang menjadi tujuan kebijakan dapat diwujudkan. Dalam hal Implementasi Kebijakan Pemerintah Nomor 47 Tahun 2008 ini untuk di Desa Kaduara Timur bisa dikatakan kurang baik karena pada kenyataannya berdasarkan keteragan sebelumnya di desa ini belum pernah ada sosialisasi secara khusus dari pihak terkait tentang pentingnya pengimplementasian Kebijakan Pemerintah Nomor 47 Tahun 2008 tentang Program Wajib Belajar Sembilan Tahun tersebut.

4. Struktur Birokasi menjadi salah satu organisasi yang paling sering menjadi pelaksana kebijakan. Dalam mengimplementasikan kebijakan mengenai Wajib Belajar Sembilan Tahun di desa Kaduara Timur ini peran birokrasi masih sangat kurang hal ini lagi-lagi dikarenakan tidak adanya sosialisasi dari birokrat yang memang memiliki kewajiban untuk menyampaikan informasi tersebut secara sungguh-sungguh kepada masyarakat desa Kaduara Timur ini.

\section{Pengaruh Budaya Lokal Pada Implementasi Kebijakan Wajib Belajar Sembilan Tahun di desa Kaduara Timur}

Kebudayaan adalah suatu keseluruhan yang kompleks yang mencakup pengetahuan, kepercayaan, seni, moral, hukum, adat istiadat, dan kecakapan-kecakapan serta kebiasaankebiasaan lainnya yang diperoleh/dihasilkan manusia sebagai anggota masyarakat (E.B. Taylor dalam Ary, 2000:16).

Menurut Herskovit (dalam Ary, 2000:19) kebudayaan merupakan sesuatu yang "superorganik" (berada di atas organisme), artinya kebudayaan turun temurun dari generasi ke generasi tetap hidup terus meskipun orang-orang yang menjadi anggota masyarakat itu senantiasa silih berganti karena kematian dan kelahiran. Memang kebudayaan tidak mungkin ada tanpa terdapatnya manusia, tetapi usia kebudayaan itu melebihi usia manusia itu sendiri (individu atau generasi).

Demikian juga dalam pelaksanaan kebijakan wajib belajar sembilan tahun di desa Kaduara Timur Sumenep Madura juga dipengaruhi oleh nilai-nilai budaya lokal yang 
keberadaanya sejak ribuan tahun silam khususnya nilai-nilai religi. Nilai religi berpengaruh besar dalam kehidupan masyarakat desa Kaduara Timur tidak hanya dalam pendidikan akan tetapi seluruh aspek kehidupan nilai agamalah yang dijadikan pedoman.

Berdasarkan hasil penelitian diperoleh data bahwa Berhasilnya pendidikan (wajib belajar sembilan tahun) di desa Kaduara Timur Sumenep Madura dipengaruhi oleh budaya, khususnya nilai-nilai religi yang sangat kental. Pendidikan khususnya pendidikan minimal sangatlah penting bagi mereka karena pendidikan tidak hanya untuk merubah kehidupan di dunia untuk menjadi lebih layak akan tetapi juga sudah merupakan anjuran dalam agama Islam hal ini sebagai bentuk refleksi dari warga desa Kaduara Timur yang beragama Islam dan menjadikan ajaran Rasul Nabi Muhammad S.A.W sebagai pegangan sebagaimana yang tertuang dalam hadist nabi Muhammad S.A.W. yang artinya:

"Barang siapa menginginkan kesenangan dunia maka dengan ilmu, Barang siapa ingin kesenangan akhirat maka dengan ilmu, dan Barang siapa menginginkan keduanya maka dengan ilmu".

Selain nilai-nilai religus berhasilnya pendidikan minimal di desa ini juga dipangaruhi oleh masuknya teknologi yang sekaligus mampu merubah perspektif masyarakat yang sebelumnya underestimate terhadap pentingnya pendidikan berubah menjadi sangat yakin bahwa pendidikan itu sangat penting tidak hanya pendidikan minimal akan tetapi semua jenjang pendidikan sampai perguruan tinggi. Selaras dengan majunya perkembangan IPTEK di jaman modernisasi ini ternyata hal ini juga memiliki pengaruh dan dampak dalam kehidupan masyawarakat desa Kaduara Timur. Masyarakat desa Kaduara Timur tidak menutup diri terhadap perkembangan IPTEK tersebut akan tetapi juga mempengaruhi kehidupan yang sedang mereka jalani saat ini "masyarakat pedesaan". Walaupun mereka tinggal di desa akan tetapi cara berpikir sudah bisa lebih maju serta modern khususnya dalam bidang pendidikan.

Sebagaimana dikemukakan oleh Nasution (2009: 21) "mencegah perubahan tidak selalu mudah karena sering ada hubungan antara perubahan materil dengan perubahan kultural. Dibukanya jalan raya ke daerah terpencil, terbukanya desa bagi surat kabar, radio, TV dan film membawa perubahan dalam berbagai aspek kebudayaan. Pola hubungan antara manusia seperti pergaulan antara anak dengan orang tua, hubungan antar seks, dan sebagainya sering mengalami perubahan yang sukar dielakkan. Demikian pula pendidikan dan sekolah tak luput dari perubahan, karena pendidikan senantiasa berfungsi di dalam dan terhadap sistem sosial tempat sekolah itu berada.

Pendidikan formal (pendidikan wajib belajar sembilan tahun) sudah berjalan sebagaimana yang diharapkan oleh pemerintah. Keberhasilan tersebut banyak dipengaruhi oleh nilai-nilai religi yang kemudian diselaraskan dengan berkembangnya Ilmu Pengetahuan dan Teknologi (IPTEK).

Dalam dunia yang dinamis ini tak dapat tidak setiap masyarakat akan mengalami perubahan. Tidak turut berubah dan mengikuti pertukaran zaman akan membahayakan eksistensi masyarakat itu (Nasution, 2009: 23).

\section{KESIMPULAN}

Berdasarkan hasil penelitian tentang Pelaksanaan Wajib Belajar Sembilan Tahun yang merupakan Implementasi dari Peraturan Pemerintah Nomor 47 tahun 2008 maka dapat disimpulkan: 


\section{REFORMASI}

1. Pelaksanaan Wajib Belajar Sembilan Tahun di desa Kaduara Timur sudah sesuai dengan harapan pemerintah karena 60 (enam puluh) persen masyarakat desa Kaduara Timur sudah menempuh pendidikan wajib belajar tersebut.

2. Nilai budaya lokal yang masih kental terasa di desa Kaduara Timur adalah nilai-nilai yang bersifat religi. Akan tetapi nilai-nilai budaya lokal yang ada tidak menjadikan masyarakat desa Kaduara Timur fanatisme dan anti terhadap nilai-nilai budaya baru yang sifatnya lebih modern. Khususnya kemajuan dalam bidang IPTEK yang mau tidak mau berdampak juga pada kebudayaan (budaya lokal).

3. Implementasi kebijakan wajib belajar sembilan tahun dipengaruhi oleh nilai-nilai religius serta masuk dan berkembangnya Ilmu Pengetahuan dan Teknologi (IPTEK) di desa Kaduara Timur Sumenep Madura.

\section{SARAN}

1. Pemerintah hendaknya lebih serius dalam mensosialisasikan setiap kebijakan dan memantau secara langsung perkembangan kebijakan tersebut sampai pada daerahdaerah yang paling bawah. Khususnya kebijakan yang berkenaan dengan pendidikan karena pendidikan ibarat nyawa, apabila ada daerah yang tidak bisa melaksanakan pendidikan dengan baik maka kehidupannya dipastikan tidak akan seperti yang diharapkan dalam Undang-Undang Dasar 1945 yang salah tujuan berdirinya negara Indonesia adalah menciptakan kecerdasan bangsa.

2. Warga desa Kaduara Timur hendaknya terus membuka diri terhadap perkembangan IPTEK akan tetapi jangan sampai melupakan nilai-nilai budaya lokal yang sudah menjadi ciri khas di daerahnya terutama nilai-nilai yang mengandung unsur religius serta kearifan lokal.

\section{DAFTAR PUSTAKA}

Arikunto, Suharsimi. 2010. Prosedur Penelitian Suatu Praktik. Jakarta: Rineka Cipta

Aristin, Rini. 2004. Skripsi Pendidikan Dalam Perspektif Budaya Lokal (Studi Praktek Pendidikan Informal di Desa Kaduara Timur Sumenep Madura). Malang: UM

George C. Edwards III dan Ira Sharkansky, The Policy Predicament: Making and Implementing Public Policy. (San Francisco: W.H. Freeman and Company, 1978), h.2.

Gunawan, Ary. 2000. Sosiologi Pendidikan Suatu Analisis Sosiologi tentang Pelbagai Problem Pendidikan. Jakarta: Rineka Cipta

Koentjoroningrat, 2002. Pengantar Ilmu Antropologi. Jakarta: Rineka Cipta

Moleong, Lexy. 2012. Metodelogi Penelitian Kualitatif. Bandung: Rosda karya

Miles, MB. \& Huberman, AM. 2007. Analisis Data Kualitatif. Terjemahan OlehTjetjep Rohendi Rohidi Jakarta: UI Press

Nasution, 2009. Sosiologi Pendidikan. Jakarta: Bumi Aksara

Nugroho, Riant. 2012. Public Policy, Dinamika kebijakan, Analisis kebijakan, Manajemen Kebijakan, Teori dan Model, Perumusan, Implementasi, Pengendalian Monitoring dan Evaluasi, Risk Management kebijakan Unggulan, The fifth Estate metode Penelitian Kebijakan. Jakarta: Gramedia

PP Nomor 47 Tahun 2008 tentang Wajib Belajar.

Ramdhani, A. dan Ali R. M. 2017. Konsep umum Pelaksanaan Kebijakan. Bandung

Solichin, Abdul Wahab. 2011. Pengantar Analisis Kebijakan Publik. Malang: UMM Press 


\section{REFORMASI}

ISSN 2088-7469 (Paper) ISSN 2407-6864 (Online)

Volume 8 Nomor 2 (2018)

Suardi, Moh. 2016. Sosiologi Pendidikan. Yogyakarta: Parama Ilmu

Sutrisno, Edy. 2010. Budaya Organisasi. Jakarta: Kencana

Triwiyanto, T. 2014. Pengantar Pendidikan. Malang: Bumi Aksara

Undang - Undang RI Nomor 20 tahun 2003 tentang SISDIKNAS

Winarno, Budi. 2014. Kebijakan Publik, Teori, Proses, dan Studi Kasus. Yogyakarta: Caps (Center of Academic Publishing Service)

Widodo, Joko. 2007. Analisis Kebijakan Publik Konsep dan Aplikasi Analisis Proses Kebijakan Publik. Malang: Bayumedia Publisihing

Yunus, R. 2016. Tranformasi Nilai-Nilai Budaya Lokal Sebagai Upaya Pembangunan Karakter Bangsa. 